ATOLL RESEARCH BULLETIN

NO. 580

RUMINANT LIVESTOCK ON CENTRAL PACIFIC ATOLLS: THE POTENTIAL IMPLICATIONS OF SOIL ON HERBIVOROUS ANIMAL SURVIVAL AND POSSIBLE IMPLICATIONS FOR AGRICULTURE AND HUMAN HEALTH

BY

TONY ALIK, BRIAN VANDER VELDE, AND NANCY VANDER VELDE 


\title{
RUMINANT LIVESTOCK ON CENTRAL PACIFIC ATOLLS: THE POTENTIAL IMPLICATIONS OF SOIL ON HERBIVOROUS ANIMAL SURVIVAL AND POSSIBLE IMPLICATIONS FOR AGRICULTURE AND HUMAN HEALTH
}

\author{
BY
}

TONY ALIK, ${ }^{1}$ BRIAN VANDER VELDE, ${ }^{2}$ AND NANCY VANDER VELDE ${ }^{2,3}$

\begin{abstract}
The introduction of large herbivorous animals into new regions for utilitarian purposes by people has been standard practice for millennia. When these animals have been brought into islands, the results have typically been ecological disaster to the delicate island ecosystems. However, the history of such introductions to atolls has not followed the same course. This paper reviews the history of attempted introductions and what information is available as to their outcomes, with focus given to the Marshall Islands. It is suggested that the nature of atoll soils prevents the survival of these animals, with possible implications to agriculture and human health as well.
\end{abstract}

\section{INTRODUCTION}

The question arose first, as to why there are no established goat, sheep or cattle populations on central Pacific low atolls such as the Marshall Islands, and second, whether this is of any significance for human health (this latter question is not addressed in this paper.)

Here we investigate written history and current understanding of some residents of the Marshall Islands to ascertain whether it is possible that the atoll soil composition of plays the major role as to why ruminants have not become established on these atolls, either in the wild or as domestic animals.

Several indications that the soil mineral content is highly significant are cited, with various possible arguments against this also being considered.

\section{DISCUSSION}

Throughout the world, feral goats have long been a notorious problem and extensive eradication programs have been undertaken, albeit not always successfully (Campbell and Donlon, 2005). So it is remarkable that no self-sustaining population of ruminants is known in the Marshall Islands or any other similar oceanic coral atoll.

\footnotetext{
${ }^{1}$ College of the Marshall Islands Liberal Arts Major; Capstone pilot program.

2 Biological Consultants, Majuro, Marshall Islands.

3 authors listed alphabetically; corresponding author; nancyv@ntamar.net
} 
Furthermore, the persistent attempts and failures to introduce ruminants demonstrate that there is indeed a problem.

Some accounts of early introductions to the Marshall Islands and other similar atoll areas include:

- 1817: The Russian Rurik under the command of Otto von Kotzebue spent weeks on Wotje and other atolls of the Ratak (eastern) chain of the Marshall Islands. They provided the people of "Otdia" (or Wotje) and other atolls with watermelon, yam, and sweet potato seeds and tubers. They also gave them goats, which had been taken aboard the vessel in Hawaii, and then left on Kāijen Island, (which was rebranded "Goat Island," a designation still to be found on some charts to this day). The first attempt to establish goats failed but another attempt was made a few months later on a second stopover (Chamisso, 1835; Chamisso [Kratz translation, 1986]).

Evidently none of the goats from either introduction survived.

- 1857: Protestant missionaries from the American Board of Commissioners for Foreign Missions arrived on Ebon Atoll. These "missionaries brought new food sources to the attention of the people" and right away "began in a small way to introduce sheep, goats, and a good breed of pigs" (Crawford and Crawford, 1967), and by the next year, more ruminants were brought "two lambs, male and female...two goats." (janeresture.com, 2009). But even though the "climate [was] pleasant, with abundance of rain... [but] it was found difficult to keep animals; there was plenty for them to eat, but some noxious plant destroyed them" (janeresture.com, 2009).

These failed introductions were reflected in one of the first books produced in the local Marshallese language:

"Kot ra'r ber i Ebon mokta.

Rar ber iben toktor Birjon.

Re ba me, me, me." (annon undtd.)

(translation:)

"Goats were found in Ebon earlier

They were with Dr. Pierson ${ }^{4}$

They said 'may,' 'may,' 'may."'

- c1860: Other missionaries from the same organization had gone to Abiang, Kiribati. They too tried to raise livestock (janeresture.com, 2009), and also met dismal failure. Thus, early on it was concluded that on the "rims of very narrow land which surround the lagoons' and where "soil is poor, and often very barren," "cattle, sheep, and goats can live there but a short time" and that: "Neither goats, nor sheep, nor cattle...can live on either the Marshall or Gilbert Islands (Bingham, 1866)."

\footnotetext{
${ }^{4}$ George Pierson, one of first missionaries to go to Ebon, was also a medical doctor.

5 A few years earlier, a similar statement was made concerning Kiribati with its poor soil where very few plants could grow,' only with a slightly different assortment of animals: "Neither horses, cows, nor sheep can live there long." (ABCFM 1885).
} 
- Before 1889: The "metropolitan islet" of Jabwor, Jaluit, although being what was called an "unpromising spot" that "a small Paradise has been created." Part of this socalled 'paradise' included "the little cow grazing quietly on her patch of freshly planted grass" (Moss, 1889).

- After 1889: Jabwor, Jaluit, cows and sheep 'can only exist when they are fed with imported grass. ${ }^{6}$ (Schnee, 1904 [Petrosian-Husa translation).

- 1896: Again on Jabwor: 'There is not enough food for cows. Those animals imported to Jaluit for slaughter, cows and male sheep, quickly lose weight and therefore soon have to be slaughtered. Everything which had been tried to acclimate cows and sheep on the Marshall Islands has failed, because the kind of grasses cannot feed the animals. ${ }^{, 7}$ (Fitzner 1896 [Petrosian-Husa translation, pers. comm.]). This was evidently despite the practice of importing "foreign" soil, from high islands such as Pohnpei (a practice continued under the latter administration of Japan) (Fosberg, 1961; Stevenson, 1914). ${ }^{8}$

- 1890: Suwarrow Atoll, Cook Islands of Polynesia, an attempt was made to introduce goats and sheep. There was "a great deal of fine, grass feathery" and the animals "ate the grass greedily" but that grass was described as being "worthless, unfortunately, for feeding animals" because "they but did not thrive, and soon dwindled and died." "It was found, on examination, that the grass did not digest but remained in balls in the intestines" (Stevenson, 1914).

It appears that eventually efforts were given up on raising cattle and other ruminants in the Marshalls, and cattle which lived in a semi-feral state on Kosrae, were brought as food to Jaluit (Sarfert, 1919 [Petrosian-Husa translation, 2008]).

More recently, there were other accounts of goats and ruminants on atolls

- 1946: One hundred-fifty goats were transported to Bikini. These were part of the menagerie of 3,619 test animals aboard the ships anchored in the lagoon during the first of the nuclear bomb tests conducted by the United States. Because goats have approximately a body mass and respiratory system to that of humans, they could provide insight into how people would be effected by a nuclear blast. (Weisgall, 1994).

- 1977: Toward the end of the administration by the Trust Territory of the Pacific Islands, there a recommendation was made for a widespread livestock program to

\footnotetext{
6 "können nur bei Fütterung mit importirtem Grase existiren."

7 "Für Rindvieh fehlt es an Futtermitteln; die von den Schiffen als Schlachtvieh nach Jaluit eingeführten Kühe und Hammel magern sehr schnell ab und müssen deshalb bald geschlactet werden. All Versuche, Rindvieh und Schafe auf den Marshall-Inseln zu akklimatisieren, sind fehlgeschlagen, weil die Grasarten sur Ernährund dierser Tiere nicht geeignet sind."

${ }^{8}$ This was done on other atolls as well. On Takaroa, Tuamotu islands, French Polynesia "herculean efforts had been made by bringing whole schooner cargoes of soil to grow some of the food plants and trees of Tahiti, but all such growths were a trivial item in the daily demand for sustenance" (O'Brien 1922).
} 
bring in cows, goats and donkeys (along with pigs and chickens) to the Marshall Islands (PII, 1977). Fodder species were planted on Majuro, possibly for such a program (Thaman and Vander Velde, 2006), but no written record or even anecdotal accounts of any large-scale animal introductions were found.

- Recent years: There have been a few introductions of goats and cows to the Marshall Islands during the past few decades. Often cows were brought for a large feast, being allowed to graze for a short while before slaughter. Small numbers of goats were periodically introduced and allowed to free-range on isolated islets.

- c2000: Three goats introduced into Majuro, were brought by ship from Australia. The goats lived in Delap village for many years in the plain view of traffic, so just about everyone knew of them. They were allowed to free-roam around a residential and graveyard area. They grazed on some grass, weeds and other nearby vegetation, but they also ate bread, pancakes, and other flour products. Effort were made to keep them away from pandanus plants. ${ }^{9}$ They never reproduced and are now gone (pers. comm. L. Zedkaia). So although they did survive for a time, this was possibly largely due to a diet of imported food that was only supplemented by local vegetation.

- 1980s and 1990s, Kiribati: A fairly large scale program was undertaken to promote goats. "Of all the shrubs in the atolls goats appear to like Scaevola sericea (salt bush) the most and on most atolls they heavily relied on it. In fact, under coconuts Scaevola sericea was the only acceptable feed consumed daily by goats (Hussain, 1987). Of the vines and creepers which are also important components of the ground cover of atolls, many were eaten by goats under some circumstances, but the legume Vigna marina was the most palatable (Hussain, 1987)" (Aregheore, 2002a).

- Tuvalu: A similar "demonstration scheme" was undertaken with goats under coconut trees. The animals mainly consumed the same species as on Kiribati. Cattle were "once introduced by a private farmer in 1950s - 60s in Niulakita island" but they evidently did not survive, because since then, no cattle are reported to exist in this country (Fifita, 2004).

- Tokelau: Another similar short-lived attempt to raise goats was also undertaken, but also without long term results (Macfarlane, 1998).

While these failures could certainly have been for any number of reasons or combination of reasons, they do not seem to rule out a soil-mineral imbalance as being a major factor.

\footnotetext{
${ }^{9}$ They were not tethered despite being reported as such (Areghore, 2002b).
} 


\section{WHY THE FAILURES?}

\section{FACTORS OTHER THAN SOIL AND WHY THESE FACTORS ARE UNLIKELY THE PRIMARY CAUSE OF FAILURES}

While we are proposing that soil factors may be very important reasons - if not the most significant of reasons - for ruminant failures on atolls, there are other important factors that should be taken into considerations. These include:

- Unfamiliarity With and Fear Of Such Animals By People.

Kotzebue recorded that the goats he attempted to introduce on Wotje were "objects of terror" to the inhabitants.

In one instance, when a member of Kotzebue's crew was presented with a nosegay (bouquet) by an older man as a gesture of friendship, a male goat, evidently recognizing the crew member, "ran up to his old companion, and as he [the goat] ran by, snatched the nosegay with such violence from the hand of the terrified [local man], that the latter received a blow with the horns; of course he and all his companions ran off with loud cries, and the [crew member] had a great deal of trouble to entice them back to their habitations, after he had driven the goats into the bushes" (Kotzebue, 1821).

While initially, it is understandable that people who were unfamiliar with large mammals would have been terrified by their presence - especially when aggressive behavior such as Kotzebue described above occurred - pigs, which can also be frightening to persons when they first encounter them, have become established on atolls, and cows, goats, and other ruminants, such as deer and carabao, survived on other Pacific Islands, such as Guam and Pohnpei.

Furthermore, people in general nowadays would not be so fearful of goats and cattle, yet as noted above, even recent attempts at introduction have failed.

- Immediate Harvesting For Feasts.

Goats and cattle have been used in for ceremonial feasts and other "community celebrations," often shortly after they were introduced into an area (Bataua et al., 1985).

Many of the recently introduced cows and goats that the authors were told about, were specifically brought for a particularly celebration - traditional birthday party, etc.

Even early on, Kotzebue, while expressing disappointment that none of the goats survived from his first attempt at introduction, consoled himself with the idea that at least by being eaten they would have demonstrated to the people how valuable a food source these animals could eventually prove to be (Kotzebue, 1830).

- Part of Nuclear Test Program.

The goats brought to the ships on Bikini were never intended to survive but neither did they go as quickly as might have been expected. Only ten percent of the animals died at the time of the atomic blast. Actually, some of the goats nonchalantly munched away at their feed throughout the blast and subsequent fires (Weisgall, 1994). 
No report was found as to the final outcome of the remaining goats, but in any case, they did not remain on Bikini.

- Disinterest and/or Mismanagement.

One report stated that goats are not to be found on atolls due to the fact that the "colonial approaches to agriculture in general ignored or neglected livestock development" (Ochetim, 1990). Another concluded that the recent goat project in Tuvulu did not succeed because of "management shortfalls" (Fifita, 2004).

However, all along, including up into modern times, ruminants, particularly goats, have been brought for livestock to Pacific atolls, including the Marshall Islands. Every foreign administration in the area has attempted to increase agriculture, including animal husbandry (Richard, 1957; Trumbull, 1959), and in many cases, by attempting to promote subsistence through agriculture, those foreign administrations "unwittingly altered the ecological balance of the islands by introducing plant or animal life for domestic use." (Peattie, 1988).

- Eating Pandanus Leaves.

Several of the people who in recent times tried raising goats in the Marshall Islands by allowing them to free-range have reported that the animals consumed spiny pandanus leaves which eventually killed them.

Granted, some spiny plants can harm livestock. Cocklebur and burdock burs "form an indigestible ball in the stomach" when eaten (Robinson, 2008/9) - a description which does sound similar to what occurred on Suwarrow.

But in many instances, goats are able to consume "very prickly plants" (McGregor, 2000). In fact "their rumen [the first of the four compartments of their stomach] is ideal for breaking down the hard woody material" and therefore goats actually have a preference for thorny plants (pers. comm. R. Boom).

Pandanus leaves, however, are also high in alkaloids (Lee, 2003). High levels of alkaloids are poisonous to livestock, and "generally are irritating to the gastrointestinal tract producing nausea, colic and diarrhea and also act on the central nervous system to produce blindness, muscular weakness, convulsions and death" (Robinson, 2008/9).

Yet pandanus is found throughout the Indo-Pacific, including islands which have had (or still have) feral goat populations (Merlin and Juvik, 1992). Did the animals not eat pandanus on these islands because they had an abundance of other food? Or was pandanus not as toxic on those islands?

The brief account of the death of goats and sheep on Suwarrow Atoll, mentions the animals 'greedily eating grass,' and although there was "pandanus here and there" (Stevenson, 1914), it does not mention the animals eating pandanus. And although young pandanus can resemble grass, it would not resemble the "fine, grass feathery" that it describes the goats consuming. 


\title{
REASONS THAT INDICATE ATOLL SOIL-MINERAL BALANCE MAY BE A MAJOR FACTOR
}

\author{
The Nature of Atoll Soils
}

Atolls are almost entirely of marine origin and therefore their soil is barely more than gravel and sand with a thin layer of humus on top - in some areas, not even that. Such "atoll soils are made up almost entirely of...calcium carbonate, with small amounts of magnesium carbonate" (Stone et al., 2000). Not only does the limited organic material render this soil "extremely nutrient deficient," but the "excessive calcium carbonate content" creates "a quick destruction of organic matter." It is also highly alkaline" with a pH value of about 8 up to as high as 9.67 (Catala, 1957; Dalla Rosa, 1993; Fosberg and Carroll, 1965). ${ }^{10}$

Consequently, there is relatively little of some important elements, such as magnesium (as mentioned above), sodium, boron and molybdenum (although some reports will imply these are in 'sufficient' amounts). The amount of sulfur is often marginal. Nitrogen and potassium are low to very low, and the trace elements (or "micro-minerals") of copper, zinc, iron and manganese are so low to be deficient, even for indigenous plant species. (Stone, 1953; Morrison, 1990; Gessel and Walker, 1992; Dalla Rosa, 1993; Teunissen et al., 1995; Stone et al., 2000; Aregheore, 2002a; Deerik and Yost, 2006). Nickel and cobalt are not mentioned in regards to atoll soils so are evidently naturally absent.

In areas which had been forested by the great bird-catcher tree (Pisonia grandis), and often where birds have added their guano, there can be extraordinary levels of phosphorus, but otherwise this element is also lacking (Fosberg, 1994; McKee, 1956; Stone et al., 2000).

Furthermore, these atoll soils are characteristically rocky, gravelly and sandy and therefore very porous with very little ability to retain water. They have a higher $\mathrm{pH}$, hence are alkaline. Salt laden winds and periodic droughts also plague the environment.

As a result of the above and other factors, it has been correctly said that:

"A most peculiar kind of island - and often a precarious environment as well - an atoll requires critical adaptations if human existence is to be sustained" (Kirch, 2002).

"Atoll soils differ in several ways from almost all other soils that have been written about or discussed in agricultural literature. As a result, much information about growing plants on continents or high islands is either inappropriate or meaningless for atolls." (Stone et al., 2000: 2; italics ours).

So it is to be expected that many plants simply cannot survive in this harsh environment, and even those that can make it, often end up malnourished and stunted. (Fosberg, 1948). Fertilizers and other soil embellishers can help some but the amount of

\footnotetext{
${ }^{10}$ The very top layer of soils derived from pure stand of Pisonia grandis with additional bird droppings, the $\mathrm{pH} 4.55$, thus, being quite acidic instead (Fosberg and Carroll, 1965).
} 
calcium can often be so high that even such drastic measures are of limited use (TSM Services undtd).

But even when plants will grow on soils with such extreme excesses and deficiencies, the chemical imbalances will tend to be reflected in plants themselves (Deenik and Yost, 2006). The plants can only take up the chemicals of what they have been grown in: "If it's not in the soil, it can't get into the plant" (Nix, 2002). Thus in turn, the plants pass only those chemicals to whatever animal might eat them, even if such proves to be toxic to such a consumer.

Adding soil on top, as was done in colonial times, proves to be of slight help and potentially of only temporary relief. The high rainfall that atolls typically receive "brings about leaching of soluble constituents at a high rate (Fosberg and Carroll, 1965).

Eventually, the imported minerals will be leached away into the high calcium soil below, until there is very little benefit left from the added foreign soil. This likely could have been what happened in the 1800 s in Jaluit, where, as mentioned above, despite bringing in non-atoll soil, all efforts to raise cows and sheep dismally failed (Fitzner , 1896).

\section{Calcium and Magnesium}

There is a livestock condition called "grass tetany" which results from magnesium deficiency (MacLean and Davidson, 1970). This deficiency is considered to be the oldest known deficiency in animals (Spångfors, 1992). This condition is found primarily in cows, although it can also affect goats and sheep but to a lesser extent than cattle. (Voisin, 1963; McDowell, 1992; Khan et al., 2008). In other parts of the world, it often occurs in the spring when cattle graze on fresh grass grown in soil with too high a proportion of calcium to magnesium. 11

When the ratio of calcium to magnesium "rises above 5:1, the risk of grass tetany becomes very significant and above a ratio of 6:1 it is extreme" (home garden soil improvement, 2007-2009). Symptoms appear rapidly and animals can die quickly, without warning. (home garden soil improvement, 2007-2009).

The soils of the Marshall Islands, although often talked about as being "abundant" in magnesium (Stone et al., 2000), have a calcium to magnesium ratio averaging 10.4 to 1 (Deenik, 2003); some areas the ratio is around 30 to 1 or even higher (Fosberg and Carroll, 1965). Furthermore, this mineral leaches easily by heavy watering and rainfall (Morgan undtd). When calcium is found in such high levels, it is known to lead to magnesium deficiency (Harvie, 2006).

Grass tetany particularly affects older animals rather than younger ones due to the amount of magnesium in their blood serum (McDowell, 1992; Voisin, 1963). It could well be that many of the animals introduced were already advanced in age, having spent a considerable amount of time on ships to get to the area.

Livestock are also at times stricken with grass tetany after "an abrupt change from a normal diet to one with inadequate available Mg [magnesium]" (McDowell, 1992). Certainly livestock fed stored hay for months on end on ships and then put ashore would have undergone a sudden and drastic change in their diet.

\footnotetext{
${ }^{11}$ A ratio of "between 2 and 7 is ideal for optimum plant growth" (Deenik 2003) without necessarily any consideration to consumption by animals.
} 
Furthermore, when there is a disproportionate amount of one element (such as calcium in the case of atoll soil), all other nutrients are "locked-out" (Aregheore, 2002a; Boom, 2002; Harvie, 2006; NextGenHydroponics, 2007). Alkaline soils (or those with a high $\mathrm{pH}$ as in is the case of most atoll soils) "make minerals unavailable to plant" (Morgan undtd). In this case, even what little of an element there may be in the soil becomes unavailable to the plants growing in such soil (Garden.ie, 2008).

When we inquired as to what happened to the 'graveyard goats' of Delap, Majuro (mentioned above), we were told that they were evidently stolen. These goats, however, although free roaming, fed on whatever grew in the area, including a considerable amount of beggar's tick (Bidens alba). The goats were kept away from the pandanus because the owners were told that pandanus would be poisonous to the animals. The goats, however, ate much old bread and bread products (pers. comm. L. Zedkaia). Goats love to eat bread, and although it is high in starch, it would not likely have had the proportionately high amounts of calcium as was likely to have been found in local vegetation.

Other Dietary Imbalances

Limitations in other elements can also cause death to ruminants.

One way this occurs is that when there is any dietary chemical imbalance, "ruminants will resort to eating toxic vegetation when there is a shortage of food and if their ration is unbalanced (nutrient in the wrong proportions). Goats in this situation may crave for nutrients that they are missing. To compensate for these deficiencies, goats may consume vegetation they would normally not eat." (McKenzie-Jakes and Tillman undtd.).

Might this be what would account for the "dead through pandanus leaves" stories - that for want of acceptable greenery containing chemicals the goats craved, the animals resorted to browsing on pandanus leaves?

The account of the almost immediate death of the goats and sheep on Suwarrow may also indicate a chemical imbalance from the soil being reflected in the grass. The original land flora of that atoll consisted of only twenty-three species of vascular plants Of these, there were just two actual grass species - bunch grass Lepturus repens and thickhead grass Digitaria stenotaphrodes (Woodroffe and Stoddart, 1992).

The former species is widespread throughout the Pacific (Whistler, 1992) and even recently was recommended as a forage grass for ruminants in French Polynesia (Aregheore, 2009). This it could not be that the species itself is poisonous.

The latter species, while found only on Pacific atolls, (although rare and endangered on Surarrow and other Cook Islands) (Cook Islands Biodiversity undtd), is also an unlikely candidate as being intrinsically poisonous. Related species, such as crabgrasses, are said to have "decent nutrient qualities as a forage for cattle" (wikipedia.org, 2009).

The only other grass-like indigenous species recorded on Suwarrow is the beach sedge, Fimbristylis cymosa, which could possibly fit the description of being a "fine, feathery grass." But it is "heavily grazed by goats, sheep and cattle" in other areas with no apparent harm (Aboudha et al., 2003). 
So it would seem that the chemistry of the soil somehow rendered one or all of the above species toxic.

Almost a century ago, a "wasting, non-transmissible" condition called "bush sickness" in New Zealand (and a variety of other names such as "pining," "vanquish," or "daising"), was recognized. It is due to mineral deficiency in the soil, initially thought to be that of iron (Aston, 1924) but later determined to be due to a lack of copper or cobalt (Boden and West, 1998). This condition can be associated with sandy soil, often those high in pumice (Aston, 1924). ${ }^{12}$ As mentioned above, atoll soils do tend to be quite deficient in iron and copper. It is interesting to note that even early on it was determined that even where the minerals are lacking, plants grown in such deficient soil can be 'apparently healthy with this small amount,' yet 'it may not be sufficient for animals' which will die if not given other feed (Aston, 1924).

In some minor cases, it is limited reproduction that prevents these animals from thriving in their newly introduced habitat and is not due to a limited food source. "Successful reproduction is dependent on a host of macro- and micronutrients and ceases well before an animal expires from deficiency of a particular nutrient" ( Dunn and Moss, 1993).

Although it is not known whether nutrient deficiency limits the reproduction of these animals, certain appropriate amounts of these nutrients (phosporus, vitamin A, protein) are needed for optimal reproduction to occur.

It is beyond the scope of this paper to say definitively whether any of these conditions caused by the unique nature of atoll soil might be the reason cattle, goats and sheep have not been able to survive on oceanic atolls. After all, grass tetany and related disorders are "complex ruminant metabolic disorder[s] ... affected by a number of factors such as forage species and mineral composition, soil properties, fertilizer practices, season of the year, temperature, animal species, breed and age" (Khan, 2008).

They may play a part or there may be some entirely unrelated factor. But as far as we could find, these chemically caused conditions have never been ruled out as to why such livestock have never succeeded in this environment.

\section{CONCLUSION}

It seems that, unlike high islands where the goats and ruminates have proved disastrous to the environment, on atolls, it is the environment that has been the disastrous demise to goats and other ruminates.

It is uncertain if it would be practical to try to determine the cause of lack of success with cattle and goats on atolls so as to be able to rectify the situation and introduce these animals as livestock. Cattle do require a tremendous amount of food and they may not be practical to raise. Goats too eat a lot of vegetation. And although goats are often promoted as living lawnmowers, they are selective feeders (McKenzie-Jakes, 2007), and as such on atolls, they would be "useful in the control of weeds under coconuts only when the majority of the weeds are accepted by the goats." (Aregheore, 2002a).

However, if a chemical imbalance is the root cause of the failure of ruminates to survive on atolls, this same imbalance could have implications to the health of humans

${ }^{12}$ Pumice is often used as a fertizilier in the Marshalls and other atolls. 
who feed on crops grown on the same soil. For example, magnesium deficiency causes not only grass tetany in cattle but also causes health problems for humans (Bender, 1995).

If, therefore, grass tetany or a variance thereof, due to the high proportion of calcium to magnesium, is the reason for the inability to raise ruminants on atolls, could people who eat crops, particularly non-traditional crops, grown on those same atolls, be setting themselves up for magnesium deficiency?

One recent study by doctors at the Harvard School of Public Health Department of Nutrition and related institutions concluded that their "findings suggest a significant inverse association between magnesium intake and diabetes risk" (Lopez-Ridaura, 2004). Other reports have linked magnesium deficiency with hypertension, heart disease, hypercholesteremia, and depression, in addition to diabetes (Fox et al., 2001). Could it be that this deficiency is at least an exacerbating factor in the so-called "lifestyle diseases" (Bataua et al., 1985; Deerik and Yost, 2006) which are plaguing the Marshalls and many other areas of the Pacific?

Potentially there may be other chemical imbalances in atoll soil affecting crops grown in such soil. Those imbalances may include some of the major elements, some with the barely studied trace mineral. Even in continental areas where soil, forage and crops are often more chemically balanced, there are "important negative consequences of these deficiencies on human health and well-being" (Brown, 2004). These consequences are now being acknowledged and there is a host of "severe clinical deficiencies, which have easily identifiable symptoms" as well as "subclincial trace mineral deficiencies" which "are quite common," but most people "do not recognize these deficiencies as a problem since they are hard to identify" (Nix, 2002). The emphasis of fertilization in agriculture around the world become the 'big three' elements - nitrogen, phosphate and potassium - a trend that "largely ignores plant demand for the remaining macro and micronutrients except where a chronic deficiency is identified" (Brown, 2004).

How much more so in the case of atolls' unique soil?

If such imbalances are involved in dietary deficiencies on atolls, it may warrant a total rethinking of the promotion of non-atoll agriculture on atolls.

Again it is beyond the scope of this report to consider the specifics of the effects of the balance of atoll soils, but our intent is to demonstrate that further investigation is warranted.

\section{ACKNOWLEDGEMENTS}

We would like to express our appreciation to the College of the Marshall Islands Capstone Pilot Project and those involved in that project, particularly Ruth Abbott and Janet Hess, for encouraging the authors to pursue their interest in the subject. (A related Power Point presentation of this subject was given by Tony Alik on May 7, 2009 to staff, students. and other interested persons at the College).

We would also like to thank all those whom we interviewed and willingly shared their thoughts and knowledge on the subject of goats and other livestock survival in the Marshalls, including Layne Zedkaia, Jerry Kramer, Michael Trevor, Takao Dominick, and Francis Reimers. 
We greatly appreciate the email support by those knowledgeable in the subject of goats and soil, such as Karl Campbell and Robin Boom, and Carmen Petrosian-Husa for her help in translating German documents into English. We also thank Vida West of Majuro and Maxine Becker (former librarian of the College of the Marshall Islands and currently at Incirlik Air Base, Turkey), who helped with proof reading this paper.

There was no specific project funding for this paper. All labor and other resources were contributed. However, this paper was produced as a project of Hermit Crab, Inc., a Marshall Islands' non-government organization, which benefited from an EU/MINSAP start-up grant.

\section{REFERENCES}

Aboudha, J. O. Z, W. M. Musila and H. van der Hagen

2003. Floristic composition and vegetation ecology of the Malindi Bay coastal dune field, Kenya. Journal of Coastal Conservation 9:97-112. http://databases.eucc-d.de/files/documents/00000433_C9.097-112.pdf

Anonymous

undated. Buk in ajiri non ro dri Marshall. Hicks-Judd Co. San Francisco, California. [photocopy from the College of the Marshall Islands Library.]

Aregheore, E. M.

2002a. Kiribati: Country Pasture/Forage Resource Profiles. The University of the South Pacific, School of Agriculture, Alafua Campus, Apia, Samoa. www.fao.org/ag/AGP/AGPC/doc/Counprof/southpacific/kiribati.htm

Agegheore, E. M.

2002b. Marshall Islands: Country Pasture/Forage Resource Profiles. The University of the South Pacific, School of Agriculture, Alafua Campus, Apia, Samoa. www.fao.org/ag/AGP/AGPC/doc/counprof/southpacific/marshall.htm

Agegheore, E. M.

2009. French Polynesia: Country Pasture/Forage Resource Profiles. The University of the South Pacific, School of Agriculture, Alafua Campus, Apia, Samoa. www.fao.org/ag/AGP/AGPC/doc/counprof/southpacific/FrenchPolynesia.ht $\underline{m}$

Aston, B. C.

1924. The Chemistry of Bush Sickness, or Iron Starvation, in Ruminants. Transactions and Proceedings of the New Zealand Institute, 55: 720-723. http://rsnz.natlib.govt.nz/volume/rsnz 55/rsnz $5500 \quad 007100 . \mathrm{html}$; http://rsnz.natlib.govt.nz/volume/rsnz 55/rsnz 55 00_007100.pdf.

Bataua, B. T. \& 13 others

1985. Kiribati: A Changing Atoll Culture. Institute of Pacific Studies of University of the South Pacific.

Bender, D. A. (ed.)

1995. Oxford Dictionary of Nutrition and Food. Oxford University Press. [through HighBeam Research]. 
Bingham, H. Jr.

1866. Story of the Morning Star: The Children's Missionary Vessel

Published by the American Board Missionary House, Boston.

www.trussel.com/kir/mornstar.htm

Boden, E. and G. P. West

1998. Black's veterinary dictionary, $21^{\text {st }}$ edition. Rowman \& Littlefield, Lanham

Maryland. [internet access through Google Book]

http://books.google.com/books? id=rxAD2cWqYI0C\&pg=PA105\&lpg=PA10

$5 \& \mathrm{dq}=\% 22$ bush + sickness $\% 22+$ iron + goats + symptoms \&source $=$ bl\&ots $=$ XQe

wYi lGM\&sig=iqAg0Iwsec 8Jfjlp2Vb-

23hM0W4\&hl=en\&ei=mzLcSZnEMYbk7APRjN2tDA\&sa=X\&oi=book res ult\&ct=result\&resnum $=1 \#$

Boom, R.

2002. Healthy Soil, Healthy Grass, Healthy Stock - The Balanced Approach. First

Virtual Global Conference on Organic Beef Cattle Production, September 02 to October, $15-2002$.

http://www.cpap.embrapa.br/agencia/congressovirtual/pdf/ingles/03en03.pdf

Brown, P. H.

2004. Principles of Micronutrient Use. IFA International Symposium on

Micronutrients. $2004 \mathrm{ag}$ new delhi brown.pdf

Campbell, K. and C. J. Donlan

2005. Feral Goat Eradications on Islands. Conservation Biology 1362-1374.

www.advancedconservation.org/library/campbell_\&_donlan_2005.pdf

Catala, R. L. A.

1957. Report on the Gilbert Islands: Some aspects of human ecology. Atoll

Research Bulletin, 59: 1-187.

Chamisso, A. v.

1835. Reise um die Weld.

http://365sterne.de/GrosseLogb/chamisso/weltreise/zitat2.html

Chamisso, A. v.; translated and edited H. Kratz

1986. A Voyage Around the World with the Romanzov Exploring Expedition in the years 1815-1818 in the Brig Rurik, Capton Otto von Kotzebue. University of Hawaii Press, Honolulu, Hawaii.

Committee of the Club

1868. Hawaiian Club Papers. Press of Abner A. Kingman, Boston, Ms.

http://ia331343.us.archive.org/1/items/hawaiianclubpape00hawarich/hawaiia nclubpape00hawarich.pdf

Cook Islands Biodiversity \& Natural Heritage

undated. Digitaria stenotophrodes, Thickhead Grass.

http://cookislands.bishopmuseum.org/species.asp? $\mathrm{id}=6068$

Crawford, D. and S. Crawford.

1967. Missionary Adventures in the South Pacific. Charles E. Tuttle Company. Rutland, Vermont.

Dalla Rosa, K. R.

1993. Nitrogen Fixing Trees as Atoll Soil Builders. Agroforesty Information Service, Forest, Farm, and Community Tree Network. 
Deenik, J. L.

2003. Correcting Soil Nutrient Deficiencies with Organic Materials in the Atoll Soils of the Marshall Islands. uhm phd 4288 r.pdf

Deenik, J. L. and R. S. Yost

2006. Chemical properties of atoll soils in the Marshall Islands and constraints to crop production. Geoderma 136: 666-681.

http://www.ctahr.hawaii.edu/DeenikJ/Downloads/Deenik chem properties a toll soils.pdf

Dunn, T. G. and G. E. Moss

1993. Effects of nutrient deficiencies and excesses on reproduction efficiency of livestock. Journal of Animal Science 70:1580-1593.

Fifita, S. T. http://jas.fass.org/cgi/reprint/70/5/1580.pdf

2004. Country Report for the So $\square$ AnGR: Tuvalu. South Pacific Commission

Fitzner, R. ftp://ftp.fao.org/docrep/fao/010/a1250e/annexes/CountryReports/Tuvalu.pdf.

1896. Deutsches Kolonial-Handbuch. Nach amtlich. Quellen bearbeitet. H. Paetel, Berlin.

Fosberg, F. R.

1948. Atoll Vegetation and Salinity. Pacific Science III: 89-92.

Fosberg, F. R.

1961. VII. Soils. In Blumenstock, D. I. (Ed.) A report on typhoon effects upon Jaluit Atoll. Atoll Research Bulletin 75: 47-49.

Fosberg, F. R.

1994. Comments on Atoll Phosphate Rock. Atoll Research Bulletin 396: 1-5.

Fosberg, F. R. and D. Carroll

1964. Terrestrial sediments and soils of the northern Marshall Islands. Atoll Research Bulletin 113: 1-156.

Fox, C., D. Ramsoomair, and C. Carter.

2001. Magnesium: Its proven and potential clinical significance. (Statistical Data included). Southern Medical Journal 94 (12):1195-1201. http://www.medscape.com/viewarticle/423568

Garden.ie

2008. Soils: Plant nutrients. Mediateam Ltd, Media House, South County Business Park, Leopardstown, Dublin.

http://www.garden.ie/gardeningskills.aspx?id=543

Gessel, S. P. and R. B. Walker

1992. Studies of Soils and Plants in the Northern Marshall Islands. Atoll Research Bulletin 359: 1-70.

Harvie, J.

2006. Cation Ratios. Biofarm Agriculture.

http://www.biofarmag.com.au/index.php? module $=$ ContentExpress\&func $=$ dis play\&ceid $=22$

home garden soil improvement

2007-2009. The Calcium Magnesium ratio in soil.

http://www.home-garden-soil-improvement.com/calcium-magnesium.html 
Hussain, M. Z.

1987. Goat development on atolls of the Pacific: Kiribati and Tuvalu experience. Alafao Agricultural Bulletin 12 (3): 99-105 [citation only, in Aregheore 2002a].

janeresture.com

2009. The History of the Morning Star; Micronesia $\square$ The First Voyage Thither. (based on the records of Hiram Bingham and Jane Warren). http://www.janeresture.com/morningstar history1/index.html

Khan, Z. I., M. Ashraf, K. Ahmad, L. R. McDowell and E. E. Valeem

2008. Transfer of Magnesium from Soil and forage to Goats Grazing in a Semiarid Region of Pakistan: Influence of Seasons and Sampling Periods. Pakistan Journal of Botany 40(5): 2127-2133. www.pakbs.org/pjbot/PDFs/40(5)/PJB40(5)2127.pdf

Kirch, P. V.

2002. On the Road of the Winds. University of California Press, Berkeley, California.

Kotzebue, O. v.

1821. A Voyage of Discovery, into the South Sea and Beering Straits, for the

Purpose of Exploring a North-East Passage, Undertaken in the years 18151818, at the Expense of His Highness, the Chancellor of the Empire, Count Romanzoff, in the Ship Rurick. Longman, Hurst, Rees, Orme, and Brown, Paternoster-Row, London.

http://ia360935.us.archive.org/0/items/voyageofdiscover03kotz/voyageofdisc over03kotz.pdf

Kotzebue, O. v.

1830. A New Voyage Round the World in the Years 1823, 24, 25, and 26. Vol. 1. Henry Colburn and Richard Bentley, London. http://www.gutenberg.org/files/25815/25815-h/25815-h.htm

Lee, K. S.

2003. The Development of an Antimicrobial Ointment from the Alkaloids Obtained from the Leaves of Pandan (PANDANUS TECTORIUS VEITCHII,

FAMILY PANDANACEAE). www.pwu.edu.ph/2007/research/compendium2003-10-theses.html

Lopez-Ridaura, R., W. C. Willett, E. B. Rimm,, S. Liu, M. J. Stampfer, J. E. Manson and F. B. Hu

2004. Magnesium Intake and Risk of type 2 Diabetes in Men and Women.

Diabetes Care 27: 1, 134-140.

http://care.diabetesjournals.org/cgi/reprint/27/1/134

Macfarlane, D. C.

1998. Grazing Livestock in the Southwest Pacific. FAO Sub-Regional Office for the Pacific, Apia, Samoa.

http://www.fao.org/docrep/004/W9676E/W9676E02.htm

MacLean, G. J. and J. H. Davidson

1970. Diagnosis of Disorders in Pastured Livestock. Down Earth 25(4): 12-16.

[AFPMB LRS \#052588]. 
McDowell, L. R.

1992. Minerals in Animal and Human Nutrition. Academic Press, San Diego, California.

http://books.google.com/books?id= VLrnbBTqSUC\&pg=PA162\&lpg=PA16 $2 \& \mathrm{dq}=\% 22$ grass + tetany $\% 22+$ voisin $+1963 \&$ source $=$ bl\&ots $=5$ rQOhhNDNc \& sig=lzaYIK yPKFIR yHs3HvAfJHCum7w\&hl=en\&ei=tUfiSYKJIoY6wOeh9iEDA\&sa=X\&oi=book result\&ct=result\&resnum $=2$

McGregor, B.

2000. What Do Goats Really Like to Eat? Goat Notes B19. http://www.acga.org.au/goatnotes/C001.php

McKee, E. D.

1956. Geology of Kapingamarangi Atoll, Caroline Islands. Atoll Research Bulletin 50: $1-38$.

McKenzie-Jakes, A.

2007. Facts About Goats. Florida A \& M University, II (I): 1-9.

www.famu.edu/goats/UserFiles/File/Facts_About_Goats.pdf

McKenzie-Jakes, A. and N. Tillman

undated. Plants Poisonous to Goats and Other Livestock in the Southeast. Getting Started in the Meat Goat Business, Florida A \& M University, I (VII): 1-6. http://www.famu.edu/goats/UserFiles/File/Poisonous_Plants to Livestock Part A.pdf.

Merlin, M. D and J. O. Juvik

1992. Relationships Among Native and Alien Plants on Pacific Islands With and Without Significant Human Disturbance and Feral Ungulates In Alien Plant Invasions in Native Ecosystems of Hawai' $i$ : Management and Research (Stone, C.P. et al., eds), pp. 597-624, University of Hawai'i Cooperative National Park Resources Studies Unit. www.hear.org/books/apineh1992/pdfs/apineh1992vi1merlinjuvik.pdf

Morgan, D. undated. What Is Plant Nutrition? The Orchid House. http://retirees.uwaterloo.ca/ jerry/orchids/nutri.html

Morrison, R. J.

1990. Pacific Atoll Soils: Chemistry, Mineralogy and Classification. Atoll Research Bulletin 339: 1-25.

Moss, F. J.

1889. Through Atolls and Islands in the Great South Sea. Sampson Low, Marston, Searle, \& Rivington, London. http://www.archive.org/details/throughatollsis100mossuoft.pdf

NextGenHydroponics

2007. Nutrient Lockout and How to Avoid It. http://www.nextgenhydroponics.com/nutrients-and-fertilization/nutrientlockout-and-how-to-avoid-it/\#more-11 
Nix, J.

2002. Trace Minerals Important for Goat Reproduction. Sweetlix Livestock Supplement System.

O'Brien, F. www.sweetlix.com/media/documents/articles/Goat_013.pdf

1922. Atolls of the Sun. McClelland \& Stewart, Toronto, Canada.

Ochetim, S.

http://www.archive.org/details/atollsofsunwithm00obriuoft.pdf

1990. Livestock Production in the Atolls: the Ignored Sector and What Should be Done. In Chase, R. G. (Ed.) A Review of Agricultural Developments in the Atolls. pp:153.

Pacific International, Inc. (PII)

1977. A Proposal for the Marshall Islands to Attain Basic Food Self-sufficiency Through an Integrated Coconut/Livestock/Crop Development Program. A Supplemental Budget Request for the Marshalls District of the Trust Territory of the Pacific Islands for the Fiscal Year 1978.

Peattie, M.R.

1988. Nan' $y \overline{\mathrm{o}}$ - The Rise and Fall of the Japanese in Micronesia. University of Hawaii Press, Honolulu.

Robinson, S. E.

2008. Poisoning of Livestock by Plants. Factsheet, Ministry of Agriculture, Food \& Rural Affairs, Government of Ontario, Canada. http://www.omafra.gov.on.ca/english/livestock/dairy/facts/87-016.htm

Sarfert, E.

1919. Kusae, 1 half-volume. In Thilenius, ed., Results of the South SeasExpedition, 1908-1910; translation by Petrosian-Husa, C. C.H. 2008, Kosrae Historic Preservation Office.

Schnee, P.

1904. Die Landfauna der Marshall-Inseln nebst einigen Bemerkungen zur Fauna der Insel Nauru. Zoologische Jahrbücher 20: 387-412.

Spångfors, $\mathrm{P}$.

1992. Some Aspects of Feeding the Endurance Horse. 341-349. In: Feeding the Performance Horse. Proceedings for the 1992 Short Course. Kentucky Equine Research Incorporated, pp. 65-78. www.ker.com/library/advances/143.pdf

Stevenson, Mrs. R. L.

1914. The Cruise of the "Janet Nichol" Among the South Sea Islands. A Diary by Mrs. Robert Louis Stevenson. Charles Scribner's Sons, New York. http://ia311536.us.archive.org/0/items/cruiseofthejanet $010315 \mathrm{mbp} / \mathrm{cruiseofth}$ ejanet010315mbp.pdf

Stone, E. L. Jr.

1953. Summary of Information on Atoll Soils. Atoll Research Bulletin 22: 1-6.

Stone, E. L., L. Migvar and W. L. Robinson

2000. Growing Plants on Atoll Soils. Lawrence Livermore National Laboratory, U.S. Department of Energy. https://eed.1lnl.gov/mi/pdf/Stone_UCRL-LR137517.pdf 
Teunissen, E., I. Ubaitoi and M. H. Powell

1995. Trees and Shrubs for Agroforestry on Atolls Forest, Farm, and Community Tree Network (FACT Net). Winrock International Institute for Agricultural Development, Morrilton, Arkansas. www.winrock.org/fnrm/factnet/FACTPUB/AIS web/AIS11.html

Trumbull, R.

1959. Paradise in Trust: A Report on Americans in Micronesia, 1946-1958.

William Sloane Associates, New York.

TSM (Total Soil Management Program) Service, Inc.

undated. Nutrient Excess and Deficiency.

totalsoil.com/TSM/mission/showmeexcess.htm

Voisin, A.

1963 Grass Tetany (translated by C.T. M. Herriott). Charles C. Thomas Publisher, Bannerstone House, Springfield, Illinois.

http://www.soilandhealth.org/01aglibrary/010106voisin/010106gttoc.html; and links

Whistler, W. A.

1992. Flowers of the Pacific Island Seashore. Isle Botanica, Honolulu, Hawaii. wikipedia.org

2009. Digitaria. http://en.wikipedia.org/wiki/Digitaria

Woodroffe, C. D. and D. R. Stoddart

1992. Substrata Specificity and Episodic Catastrophe: Constraints on the Insular Plant Geography of Surrarrow Atoll, Northern Cook Islands. Atoll Research Bulletin 362: 1-19. 